\title{
The Correlation between the Value of Mortgage-Backed Securities \& the Value of FTSE 100 Shares Price Index: September 2013 Prices
}

\author{
Ghada Gomaa A. Mohamed ${ }^{1}$ \\ ${ }^{1}$ Associate Professor of Economics, School of Business, Ahram Canadian University, Egypt \\ ${ }^{2}$ Research Chair, ECO-ENA: Economics \& ECO-Engineering Associate, Inc., Canada \\ Correspondence: Ghada Gomaa A. Mohamed, PhD, PDFs, Associate Professor of Economics, School of Business, \\ Ahram Canadian University, Egypt.
}

Received: December 7, 2020

doi:10.11114/aef.v8i2.5156

\author{
Accepted: Janauary 6, $2021 \quad$ Available online: February 8, 2021 \\ URL: https://doi.org/10.11114/aef.v8i2.5156
}

\begin{abstract}
Using the latest information and prices for mortgage-backed securities in September 2013 this analytical piece tests the correlation between the value of these instruments and the value of the FTSE 100 share price index.

The correlation between the value of mortgage-backed securities and the value of FTSE 100 shares price index.

Keywords: mortgage-backed securities, MBS, FTSE 100 shares price index

\section{Introduction}

This analytical piece tries to address the correlation between the value of mortgage-backed securities (MBS) and the value of the FTSE 100 shares price index. It depends on the last data available for the top mortgage-backed securities traded by constituents in the UK and the last updated market value of the top listed constituents in FTSE 100. in 2013. The methodology of the analysis doesn't follow the regular statistical correlation analysis since the accuracy and robustness of results go beyond just a simple correlation analysis. Some qualitative analysis is performed first to logically specify the main determinants of each variable in question; namely; the value of FTSE 100 shares price index from one side and the value of top mortgage-backed securities traded by constituents listed in FTSE 100 from the other side. Once those determinants are accurately specified; a simple statistical correlation analysis can be performed. Hence; interpretations of results can give a more accurate conclusion. This article is hence structured to analyze first the main determinants of the value of FTSE 100 shares price index from the last updated data on the FTSE website and London Stock Exchange in 2013. It then presents a brief analysis of the determinants of the value of top mortgage-backed securities traded by constituents listed in FTSE 100 from its main source namely Mortgage News Daily and London Stock Exchange. Finally, the article presents a simple statistical correlation analysis that depends on qualitative and quantitative analysis to control for other interrelated variables. The conclusion follows the statistical analysis.
\end{abstract}

\section{FTSE 100 Shares Price Index}

The FTSE 100 shares price index includes the most highly capitalized UK companies listed on the London Stock Exchange. From the last updated data of September 14th, 2013 the value of the market can be easily determined by data on shares prices and shares traded volume on that day. From this departure point, we can always extend the time path to include historical figures. From the last updated data, one can figure out that 46 listed companies out of 100 companies traded with a share price below 1000 pounds, 54 listed companies out of 100 companies traded with share price above 1000 pounds, 21 listed companies traded with share price above 2000 pounds but only 10 listed companies out of 100 companies traded with share price above 3000 pounds. On the other side and as long as the value is determined by both the share price and its daily traded volume, then a quick analysis of the volume of the index in the same day can show that 56 listed companies out of 100 companies traded with above 1,000,000 shares on that day, 37 listed companies out of 100 companies traded with above 2,000,000 shares, 23 listed companies traded with above 3,000,000 shares, 15 listed companies traded with above 4,000,000 shares a day, 13 listed companies traded with above 5,000,000 shares a day, and finally 10 listed companies traded with above 6,000,000 shares. The analysis then focuses on the 10 top active constituents that drove the index in that day, not on the highest cap- constituents listed in the index. The top active constituents according to the last data in the market were Vodafone Group (VOD), then Lloyds Banking Group (LLOY), 
then Barclays (BARC), then Glencore Xstrata (GLEN), then ITV (ITV), then HSBC Holdings (HSBA), then Tesco (TESCO), then Morrison (Wm) Supermarkets (MRW), and finally Royal Bank of Scotland Group (RBS). The last constituent was included because its value on that date was very close to the 10th most active constituent. Top 10 active constituents were only selected out of 100 constituents to have a robust analysis at a maximum $10 \%$ significant rate and then at a maximum 5\% significant rate by focusing on the most 5 active constituents.

\section{Mortgage-Backed Securities}

Having known the fact that the Mortgage-Backed Securities (MBS) are bonds that are backed by pools of mortgage loans and the agencies issue them: Fannie Mae, Freddie Mac, and Ginni Mae can give the first impression that the top active shares affected the value of FTSE 100 has nothing to do with the value of those instruments. Nonetheless, from the last updated figures in Mortgage News Daily, one can figure out that the listed MBS movements are determined depending on bonds maturity and interest rates. Besides, the term calculations differ from the determinants of the FTSE 100 shares price index. However, with an emphasis on the MBS in the UK, we can figure out that top mortgage-backed securities in the UK are traded by HSBC, Chelsea Building Society, Yorkshire BS, First Direct, NatWest, RBS, Principality Building Society, Natwest, and Ardmore. Accordingly, and for a coherent analysis, any of those constituents' shares values listed in FTSE 100 should be compared with the value of the index itself and in the same period to figure out the correlation among them. Comparing the values of mortgage-backed securities themselves and FTSE 100 is a wrong approach because it contradicts the logical consistency of comparing different measures. Hence the correlation analysis focuses only on the MBS-traded by top constituents listed in FTSE 100 for consistency. The HSBC, for example, is ranked the second constituent listed in FTSE 100 with a market cap of 129 billion pounds. At the same time, it is listed among the top 10 active constituents that drove the index's value according to the last updated figures. The RBS also issues MBS, and it is listed on the top list. According to Mortgage News Daily, other banks listed among the top active constituents issue MBS, but they are not on the top list of the MBS traded. Using this logic, a simple correlation analysis is presented in section 3 .

\section{The Correlation Analysis}

The null hypothesis of the analysis is proposed as follows:

$$
\begin{aligned}
& \mathrm{H}_{0}: \wp=0 \quad \text { at } \rho \leq 5 \% \text { significant rate. Hence; the alternative hypothesis can be written as follows: } \\
& \mathrm{H} 1: \wp \neq 0 \quad \text { at } \rho \quad \leq 5 \% \text { significant rate; where; } \wp \text { is the correlation coefficient. }
\end{aligned}
$$

Table 3-1 shows the correlation results of the link between the value of the top 10 active constituents listed in FTSE 100 and the aggregate value of FTSE 100 itself. Data are collected from the market by using historical daily data for September only as of the last updated figures in the market.

Table 3.1. The correlation results

\begin{tabular}{|l|l|}
\hline $\begin{array}{l}\text { Top 10 (11) active constituents in } \\
\text { FTSE100 }\end{array}$ & Correlation Coefficient \\
\hline VOD & -0.328877 \\
\hline LLOY & 0.918128 \\
\hline BARC & -0.874684 \\
\hline GLEN & -0.930395 \\
\hline BP & -0.196044 \\
\hline ITV & -0.842262 \\
\hline HSBA & 0.620598 \\
\hline BT.A & -0.828877 \\
\hline TSCO & -0.607180 \\
\hline MRW & -0.868234 \\
\hline RBS & -0.885532 \\
\hline
\end{tabular}


Table 3-1 shows that the value of FTSE 100 is positively correlated with the value of Lloyd's shares and secondly with the value of the HSBA's shares. Both constituents issue MBS. Also, the RBS has a high but negative correlation with the value of the index. Because HSBC is the top constituent that trades MBS, according to Mortgage Daily News, the result's interpretation emphasizes the figures of this constituent. By eliminating this constituent from the analysis, the correlation coefficient has been significantly reduced. The plausible interpretation of this result is that the HSBA has a significant impact on the index's value according to the last updated data. Also, by performing a simple regression analysis, the correlation between the value of HSBC Holdings (HSBA)'s shares, and the value of FTSE 100 was significant at less than 5\%. Because the RBS was also listed among the top traded MBS constituents according to Mortgage News Daily; the average of the value of both the HSBA and the RBS was measured to figure out its correlation with the value of FTSE 100, and evidence found that the correlation is still negatively above $0.50 ; \wp=$ -.636243 but by taking the weighted average; evidence found that the correlation is negative and less than $0.50 ; \wp=-$ 0.490602. However, we cannot exclude the high correlation of the value of LLOY because it trades MBS, but it's not listed among the top traded constituents in Mortgage News Daily.

\section{Conclusion}

A high significant positive correlation between the value of the top constituent trades with the MBS in the UK and the value of FTSE 100 was found according to the proposed analysis in this article. This result cannot however give an implication regarding the correlation between the values of the MBS specifically and the value of FTSE 100 because of the inconsistency of measuring both of them. An extended qualitative analysis should be performed to analyze the HSBA's securities and the weight of each of its securities in its daily traded volume. Yet; this analytical article can give a good threshold for a deeper analysis.

\section{References}

London Stock Exchange Website: http://www.londonstockexchange.com/exchange/prices-and-markets/stocks/indices/summary/summary-indices.ht ml?index=UKX

FTSE website: http://www.ftse.com/

FTSE 100 on Wikipedia: http://en.wikipedia.org/wiki/FTSE_100_Index

Mortgage-Backed Securities MBS prices: http://www.mortgagenewsdaily.com/mbs/

Mortgage rates and markets data: http://www.mortgagenewsdaily.com/mortgage_rates/

Why do MBS's matter to mortgage rates? http://www.mortgagenewsdaily.com/mortgage_rates/mbs-mortgage-rates.aspx

FTSE 100 Price Index http://shareprices.com/ftse100

Money.co.uk, http://www.money.co.uk/mortgages.htm

FTSE 100 historical data: http://www.investing.com/indices/uk-100-historical-data

\section{Copyrights}

Copyright for this article is retained by the author(s), with first publication rights granted to the journal.

This is an open-access article distributed under the terms and conditions of the Creative Commons Attribution license which permits unrestricted use, distribution, and reproduction in any medium, provided the original work is properly cited. 